\title{
Violências, Sistemas Violentos e o Horizonte Testemunhal
}

\author{
Violences, violent systems and the testimonial horizon \\ Violencias, sistemas violentos y el horizonte testimonial
}

Paulo Cesar Endo

Universidade de São Paulo

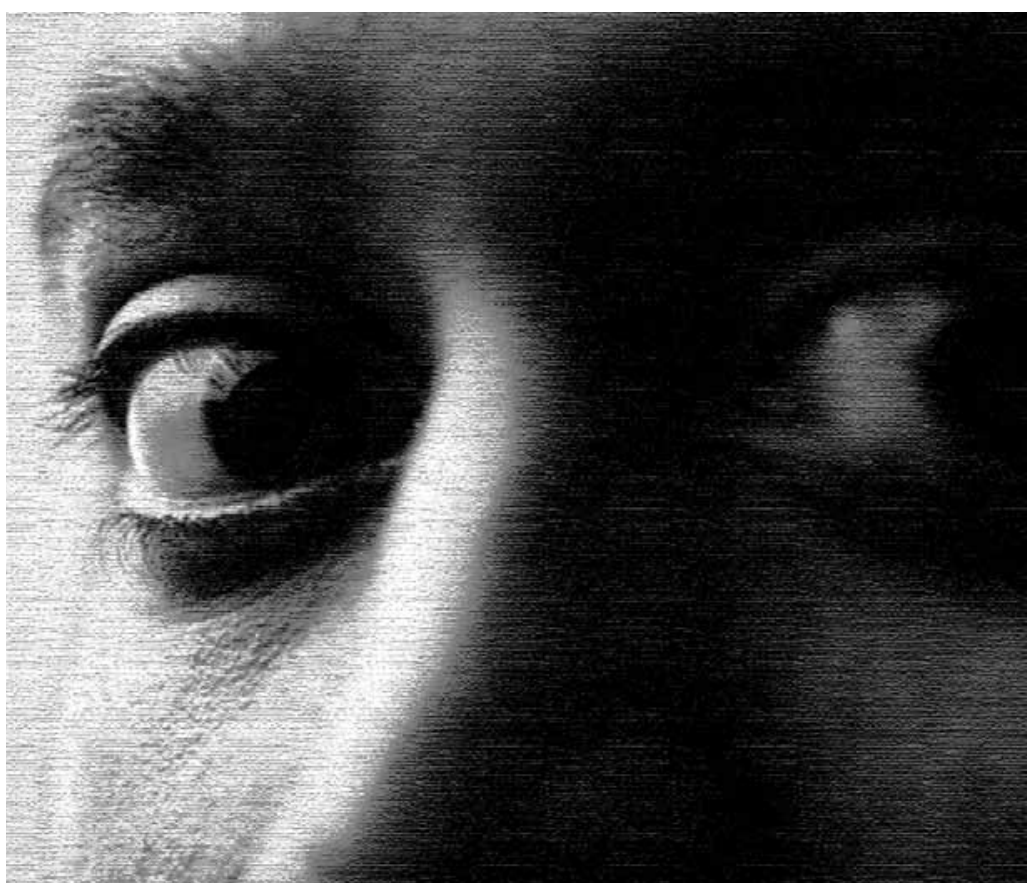


Resumo: Este trabalho discute as formas contemporâneas de engendramento e oposição às expressões violentas de resolução de conflitos. O pano de fundo dessa discussão é o debate sobre a violência institucional e urbana no Brasil nas últimas décadas. Destacaremos o testemunho como expressão política, psíquica e social emergente ao lado do recrudescimento dos linchamentos, a partir da década de 80, dos homicídios praticados por agentes do Estado e do crescimento dos índices de homicídios como formas de resolução de conflitos. Não raro, no seio da violência desregrada, viceja um conjunto de valores que são exercidos de modo brutal radicados na disputa entre valentões e "cabras- machos" que, a todo custo, pretendem ratificar sua posição num sistema violento que, para se preservar assim, exige cada vez mais valentões dispostos a colocar a própria vida e a vida alheia em risco. A virilidade combalida aparece, então, como célula subjetiva mantenedora dos sistemas violentos.

Palavras-chave: Violência. Subjetividade. Psicanálise. Testemunho.

\begin{abstract}
This paper discusses the contemporary forms of engenderment and opposition to violent expressions in conflict resolution. The focus of this work is the discussion about the institutional and urban violence in Brazil in the last decades, in which the witness emerges as a political, psychological and social expression in addition to the increase of lynchings, since the 1980s, and the homicides carried out by agents of the state, as well as the rising of the homicide rates in Brazil as a way of resolving personal conflicts. At the heart of this out-of-control and excessive violence, there is a set of values that are nurtured and brutally practiced. These values are based on the dispute between bullies and alpha males, who intend to justify their position in a violent system at any cost, a system whose preservation depends on the demand for more and more bullies who wish to put their own lives and the lives of others at risk. So, this fragile virility appears as a subjective cell capable of preserving violent systems.
\end{abstract}

Keywords: Subjectivity. Psychoanalysis. Testimony.

Resumen: Este trabajo discute las formas contemporáneas de engendramiento y oposición a las expresiones violentas de resolución de conflictos. El telón de esa discusión es el debate sobre la violencia institucional y urbana en Brasil en las últimas décadas. Destacaremos el testimonio como expresión política, psíquica y social emergente al lado del recrudecimiento de los linchamientos, desde la década de 80, de los homicidios practicados por agentes del Estado y del crecimiento de los índices de homicidios como formas de resolución de conflictos. No raro, en el seno de la violencia desreglada, produce un conjunto de valores que son ejercidos de modo brutal radicados en la disputa entre valentones y "tipos" que, a todo coste, pretenden ratificar su posición en un sistema violento que, para se preservarse así, exige cada vez más bravucones dispuestos a poner la propia vida y la vida ajena en riesgo. La virilidad comalida aparece, entonces, como célula subjetiva mantenedora de los sistemas violentos.

Palabras clave: Violencia. Subjetividad. Psicoanálisis. Testimonio.

\title{
Violências, sistemas violentos e o horizonte testemunhal
}

Não faz muito tempo, a discussão sobre a violência nas ciências sociais e políticas restringia-se a uma dicotomização tão exata quanto imprecisa: a violência nas cidades brasileiras era fruto da colisão entre o Estado e a sociedade civil. Leitura de traçado marxista que focava a violência social no Estado torturador, homicida e cruel, era o momento de uma luta urgente contra os abusos do Estado ditatorial brasileiro e da esperança num futuro promissor, patrocinado pelos auspícios da democracia que, na década de 1980, vimos dar seus primeiros passos.
A década de 1980 enfrentou uma dicotomização entre aqueles que denunciavam a miséria, a degradação da educação e a precarização da saúde como forjadores da violência - considerados como partidários da esquerda penal - e aqueles que examinavam os sistemas de segurança, incluindo o aparato policial, visando a criticá-lo, mas, ao mesmo tempo, propondo reformas na concepção de segurança pública que objetivavam a sua adaptação ao funcionamento do Estado Democrático de Direito. Esses eram considerados de direita. 
"Os principais implicados nos crimes do esquadrão que passaram a atuar no campo da polícia política, integrando o sistema de segurança, ao qual transmitiram suas técnicas de ação"

(Bicudo, 2002, p. 1).
Eles pleiteavam um exame e uma vigilância melhor das polícias, a fim de transformá-la numa instância que atendesse os requisitos básicos de respeito e eficiência no contexto de uma sociedade democrática.

Essa tendência ganhou corpo e adeptos, e foise incluindo na relação com o aparato policial uma obrigação ética de transformação a serviço da sociedade civil, posição que era recusada pela esquerda penal, incapaz de admititr a polícia senão como braço repressor do Estado. Esse debate, ainda que menos dicotomizado, perdura até hoje.

No Brasil da década de 1970, pouco se falava, no pensamento sociológico brasileiro, sobre a violência ligada à criminalidade e à segurança pública. Com algumas exceções, o pensamento social brasileiro voltava-se para a formação e a dinâmica dos movimentos sociais, vendo aí uma fonte de inspiração inestimável para o pensamento e a ação. Os quebra-quebras urbanos, os movimentos messiânicos ou do cangaço, as passeatas e manifestações de rua e a repressão deles decorrente revelavam o fulcro de onde muito se poderia extrair e aprender. Em decorrência, o que se tornou patente e politicamente correto foi a análise dos conflitos entre a violência "legítima", advinda da sociedade civil contra a violência do Estado ditatorial, "ilegítimo" e ilegal.

Tínhamos então, do ponto de vista da esquerda penal, de um lado, a violência fortemente vinculada ao Estado autoritário e ao governo militar, e, do outro, a violência popular e legitimada pela análise do pensamento de esquerda nacional como modo de reação a um sistema opressor e ilegítimo.

A violência era tida como instrumento de mudança e libertação e, ao mesmo tempo, como forma de manter o status quo e a dominação.
Já na década de 60, concomitantemente à instauração do regime militar, vimos o surgimento da violência policial ligada a grupos de extermínio, aos esquadrões da morte, a justiceiros e depois ao tráfico de drogas, ao jogo do bicho e à prostituição. Essas estruturas ganharam força e notoriedade e adquiriram uma virulência, já prevista na década de 1980, que hoje ameaça se imiscuir nas instituições ligadas diretamente à defesa nacional.

Com isso, ficam demarcadas as dificuldades crescentes em promover, propagar e até mesmo conceber o funcionamento de uma polícia cidadã num Estado Democrático de Direito, isto é, a polícia a serviço da cidadania e da preservação da vida, e não a serviço do Estado militarizado e do capital privado, prática que se alastrou em muitos países, e no Brasil muito especialmente. Para alguns, realizar essa transformação no Brasil é tarefa inexeqüível.

Havia, já na década de 1960, a polícia repressora, braço armado do Estado que convivia bem com outras práticas abusivas. Bicudo esclarece sobre a ação dos esquadrões da morte nesse período, "Os principais implicados nos crimes do esquadrão que passaram a atuar no campo da polícia política, integrando o sistema de segurança, ao qual transmitiram suas técnicas de ação" (Bicudo, 2002, p. 1).

Vejam que interessante, então, se pudermos pensar nessa perspectiva sugerida por Hélio Bicudo: a polícia política repressiva, instrumentada pelo Estado brasileiro, fez escola antes, nas ruas, matando pobres. A origem, portanto, da prática policial torturadora e assassina dos anos de repressão resultaria de uma associação espúria visando à privatização do público, isso levado a cabo por uma prática policial desregulada, que agia em nome de interesses particulares e do Estado repressor que reprime, em última instância, para também privatizar o poder. 
"Quem apanha é pobre; colarinho branco não apanha, faz acerto"

(Caldeira, 2000, p. 107).
Mais ainda, quase quatro décadas depois do surgimento dos primeiros esquadrões da morte, temos de ouvir Benedito Mariano, em 2001, na ocasião ouvidor de polícia do Estado de São Paulo, afirmar: "a polícia brasileira em Estado de normalidade democrática mata pobre".

Nenhuma novidade para aqueles que freqüentam as páginas dos jornais. As violências praticadas pelas polícias brasileiras repousam sobre o exercício da função viril, no combate entre machos, em que a aniquilação do oponente produz a vitória, mas, para isso, depende intrinsecamente da aquisição de privilégios, que são obtidos pela via do uso privado do patrimônio público, o que inclui a farda, a arma, o carro e a função, devidamente remunerada e socialmente reconhecida. É essa inversão que lhe permite fazer da violência um produto caro, vendido aos que podem e querem pagar. Paga-se para matar, para proteger a vida como patrimônio privado, para não apanhar. Esse é o verdadeiro ganho potencial de nossas polícias, que executam a sentença: "Quem apanha é pobre; colarinho branco não apanha, faz acerto" (Caldeira, 2000, p. 107).

Isso que freqüenta as práticas homicidas como uma espécie de ideal masculino estável, a figura do valentão, "cabra macho" e justiceiro bem pago num mercado promissor, consolidou-se no Brasil como um dos problemas graves que hoje adquire feição epidêmica. É a proliferação dos esquadrões da morte, que atualmente se espalham por 15 dos 26 Estados brasileiros. O crescimento e a manutenção das altas taxas de homicídio no País são reveladores dos avatares das formas extremas de solucionar conflitos na sociedade brasileira pós-ditadura.

Lembremos que esse problema já era notório no início da década de 1980, o que levou à instauração, em 1982, no governo Montoro, de comissões de investigação sobre os justiceiros e esquadrões da morte bem como, na mesma época, eliciou uma reação de setores da sociedade civil contra tais investigações.

Desde então, o problema só se agrava e assume os contornos tão temidos do crime organizado, isto é, crimes realizados com apoio e patrocínio de membros dos Poderes Executivo e Legislativo brasileiros. No Espírito Santo, terceiro Estado da Federação que mais mata, acompanhamos a extinção legal das atividades da Scuderie Detetive Le Coq em fevereiro de 2005. A Scuderie é um grupo paramilitar que age, há décadas, como esquadrão da morte, isso 20 anos após seu surgimento, em 1984.

Antes disso, em 1970, era criada a Ronda Ostensiva Tobias Aguiar, grupo policial instituído para caçar e matar guerrilheiros urbanos, aparelhado com armamento pesado, e que continua "patrulhando" as cidades paulistas décadas após a transição democrática, caçando e matando a população pobre.

Só como exemplo, tivemos, em 1992, ano do massacre do Carandiru, mais de 1.400 pessoas mortas pelas polícias paulistanas. Esse número oscilou nos anos seguintes, até atingir patamares alarmantes em 2003, quando mais de 800 pessoas foram mortas pela polícia paulista, o segundo maior índice da década.

Há alguns anos, durante o governo Fernando Henrique Cardoso, o então ministro Miguel Reale apoiou radicalmente uma intervenção federal no Espírito Santo para coibir a ação desses grupos de homicidas organizados. Esse apoio e a relutância do governo federal em realizar a intervenção motivaram sua demissão.

A ausência e o recuo do Estado em enfrentar um problema público num outro Estado da Federação tipifica a lentidão das formas 
institucionais de justiça que raramente chegam onde não estão os afortunados. É precisamente nesse sentido que a justiça, com a polícia, se privatiza.

O agravamento das formas de violência letal e a deterioração do espaço público ocorrem concomitantemente e se alimentam do mesmo fulcro que dissemina e institucionaliza desigualdades radicais, criando espécies populacionais diferentes na mesma cidade, no mesmo país. Em outras palavras, as redes de tráfico, a polícia corruptível e o conservadorismo do Judiciário giram em torno de um mesmo moto-contínuo: a aspiração de privatizar o que é público como forma de ganho pessoal extraordinário que promove, entre aquele que corrompe e o que é corrompido, um compromisso estável, de segredos mútuos, enfatizando uma forma primitiva, simbiótica e perversa de corrosão do espaço público.

Trata-se de uma simbiose perversa, que recusa a castração imposta pela ocupação do espaço público. O público, precisamente nesse sentido, representa a face degradada que convoca a atenuação dos narcisismos para a constituição de um terceiro espaço, um terceiro lugar onde o eu recolheria seus investimentos, gratificações e angústias da experiência necessariamente compartilhada, no estar entre outros, como diria Hannah Arendt (1998) a propósito da política.

Há uma peculiaridade nessa passagem. Cada vez mais as redes de controles violentos se radicam e se institucionalizam na cidade - por meio de redes de tráfico, das polícias violentas e corruptas, da pequena criminalidade, da presença cada vez mais ostensiva da segurança privada -, na mesma medida em que elas se fazem pela via da deterioração do espaço público.

Só assim, lesando, cooptando ou seqüestrando o que, por princípio, seria espaço desejante comum, é que a cidade inteira vai sendo recortada em função do evidente interesse de alguns e, desse modo, é tiranizada, oligarquizada.

O conflito de interesses recua para formas de soluções privadas que tendem a negar a persuasão, a ação e o convívio público próprios ao exercício da política, uniformizando as possibilidades de enunciação heterogêneas e singulares, geradoras de tensão, em prol das formas hegemônicas de ocupação/usurpação da cidade, verdadeiras operações urbanas, instrumentadas pela violência e pela lei do mais forte.

A violência galga, então, o primeiro lugar como recurso extremamente eficaz, que incide na construção ou destruição das cidades, guardando uma promessa secreta obtida por via de sua inequívoca força traumática e de quem melhor souber utilizá-la: se obedecermos enquanto nos usurpam, seremos poupados do pior. É o que exemplifica o toque de recolher não só nos bairros dominados pelo tráfico, mas em todas as áreas, centrais ou periféricas, das grandes cidades onde se tornou perigoso circular. Estamos todos sob a vigência do toque de recolher.

Esse desenho da cidade tende a empurrar todos para dentro de suas próprias casas e reafirma o espaço do lar como refúgio do espaço público, cisão entre a casa e a rua que sugere que o mundo pode e deve ficar resguardado dentro de casa, tal como defende uma das maiores aliadas das violências: a mídia televisiva. Produtos para abastecer o lar e violências na dose certa são vendidos, com segurança, para os que desistiram do espaço público.

Uma nova e importante questão é proposta com a sucessão de linchamentos ocorridos na década de 1980. Teoricamente, tornouse difícil atribuir ao linchamento, dentro de 
uma perspectiva marxista, a legitimidade de uma violência justa e revolucionária, uma vez que ela é praticada entre iguais; além disso, a responsabilidade, só muito indiretamente, poderia ser atribuída ao Estado, pela ausência de dispositivos confiáveis de solução de conflitos.

Tratava-se de uma justiça coletiva feita com as próprias mãos, mãos de pessoas comuns que se sentiam de algum modo aviltadas e reconheciam na vingança uma forma de aplacar sua dor, sua vergonha, seu medo. A população insurgente desistia de esperar pela justiça institucional e partia para a resolução informal.

Se nesses casos, por um lado, podia-se ver a reprodução de práticas de justiça arbitrárias, aqui e ali uma certa identificação com as práticas militares, um atentado contra os direitos humanos, por outro lado, não se podia deixar de perceber, em vários casos, a justiça popular em ação.

Mais recentemente, a violência nas classes populares foi flagrada como a manifestação de um ethos guerreiro e da manifestação interpessoal de virilidade e afirmação de um imaginário sobre si mesmo que permite viver e freqüentar o lugar e a comunidade segundo códigos muito precisos, cuja desatenção pode levar à morte do desatento. A verdade sobre isso esbarra no imperativo da sobrevivência física e psíquica, que ora se confundem.

Aqui creio que é a Freud que deve ser dada a palavra. O eu triunfa sobre a morte quando se percebe capaz de matar. Com a morte de quem podia nos matar (o tirano), fundase uma nova ordem que exige mediações, pactos, regras e rituais.

Eles não são estáveis, até porque o assassinato abriu um precedente que não mais será esquecido, aliás, paga-se caro por cada esquecimento do assassinato cometido: com a necessidade e a urgência de um novo assassinato.

O extermínio, portanto, não é uma estratégia de equilíbrio social, cujo efeito seria uma espécie de homeostase coletiva, como quer Girard (1998) em sua leitura de "Totem e Tabu"; ao contrário, ele é o efeito do esquecimento do assassinato cruel que um dia cometemos, ou que um dia poderemos vir a cometer, e que é inteiramente atualizado na experiência do ódio. É, sabemos, da perlaboração do ódio que dependem as formas de solução de conflito que não terminam com a aniquilação do oponente.

A expressão do ódio promete conjurar a ação e o apaziguamento, o que a justiça, de outro modo, também promete fazer.

\section{Testemunho e resistência}

Nos últimos anos, vimos concorrer com o crescimento do desrespeito aos direitos civis a afirmação desses mesmos direitos. A institucionalização das ouvidorias de Polícia em vários Estados brasileiros, os programas de proteção à testemunha, as passeatas e os movimentos nas periferias das cidades e o aparecimento de uma incipiente literatura de testemunho sobre as tragédias brasileiras convivem lado a lado com o aumento da violência policial na maioria dos Estados brasileiros, com o recrudescimento das torturas nos locais de detenção e com a imediata priorização das violências cometidas contra as camadas médias e ricas nas páginas dos jornais. O crescimento dos testemunhos da população pobre, nos últimos anos, passa ao largo da exigência jurídica para revitalizarse como uma forma de intervenção discursiva e singular no espaço público. Dar a própria versão dos fatos, perseguir o acontecido, revela um esforço em publicizar a dor, buscando um reconhecimento e reparação coletivos e públicos. Desconcentra-se, assim, do âmbito privado, a inteligibilidade daquilo 
que tem sua gênese na convivência com formas públicas degradadas geradoras de desconfiança, ódio e anseios de vingança diante da demanda urgente por justiça.

Devemos à literatura de testemunho produzida em torno do Holocausto o reconhecimento alteritário de nossa dignidade e humanidade próprias sendo tragada e degradada no corpo do povo judeu. Pudemos nos sentir empaticamente tocados e comovidos com dores distantes e pudemos reconhecer, mais e melhor, o fenômeno do Holocausto como um atentado contra a humanidade, e não apenas contra os judeus.

Como afirma, então, Arendt (1999): “...o extermínio físico do povo judeu era um crime contra a humanidade, perpetrado no corpo do povo judeu..." (p. 291).

Os testemunhos demonstram a impossibilidade de esgotar um assunto enraizado na singularidade dos que a viveram e se tornaram, por assim dizer, porta-vozes de um acontecimento que precisa ser singularizado para chegar ao outro, apelando para uma outra inteligibilidade que reata vínculos identificatórios com o horror.

No Brasil, não há tantos testemunhos sobre nossos horrores, sobre nossos massacres. No caso dos horrores, só claramente constatados após a década de 1980, as vítimas, ou testemunhas - preferencialmente negros, pobres, entre 15 e 24 anos, do sexo masculino -, não dominam o hábito da escrita, do registro.

O rap surgiu nesse vácuo e tornou-se, especialmente para os jovens da periferia paulistana, um veículo testemunhal.

Nesse particular, há qualidades diferentes de letristas de rap, entre os quais o grupo Racionais Mcs tem evidente destaque. A importância de certas letras de rap reside nesse caráter testemunhal, nessa afirmação do testemunho como forma de chegar à verdade encoberta no outro, naquele que não a viveu, não a viu e que se sente subjetivamente alheio aos acontecimentos que, a princípio, não lhe são pertinentes.

São as letras isentas de pregação moral e panfletarismo as que melhor representam o testemunho do jovem da periferia paulistana.

Tô Ouvindo Alguém me Chamar, música e letra dos Racionais, é um bom exemplo de um quase-testemunho que vai desfiando em detalhes os elementos de formação da ascensão e ruína no itinerário do crime pela via da ilegalidade e da violência. Revela-se aí, de forma sincopada, aquilo que mais particularmente na década de 1990 podemos chamar de constituição e ruína de um ethos guerreiro como uma das referências identificatórias disponíveis ao jovem pobre das metrópoles brasileiras. Diz a letra:

Tô ouvindo alguém me chamar Foi professor no crime Também maior sangue frio não dava boi pra ninguém

Puta, aquele mano era foda

Só moto nervosa

Só mina da hora

Só roupa da moda.

Depois, após o personagem ter sido baleado a mando de um amigo seu, parceiro de um assalto malsucedido, a letra continua:

Sonhei que uma mulher me falou, Eu não sei o lugar

Que um conhecido meu (quem?) ia me matar

Precisava acalmar a adrenalina

Precisava parar a cocaína

Não tô sentindo meu braço

Nem me mexer da cintura pra baixo Ninguém na multidão vem me ajudar 
Que sede da porra, eu preciso respirar. Cadê meu irmão?

A letra e o som ritmados e repetitivos são eloqüentes: os elementos constitutivos do sujeito sobrevivente, em cujo enunciado ele se implica e se confunde e que fazem da experiência da castração uma experiência necessária, uma limitação na onipotência do desejo de cada um de nós, ressurgem para o rapaz pobre e ambicioso pela morte prematura que um disparo produz: castração realizada à bala.

Aqui a constatação de que se pode tudo, justamente para podermos o possível, não é dada pelas formas linguageiras e os benefícios da cultura - onde as leis são uma de suas expressões -, mas são noticiadas ao menino pobre pela violência que o atinge e do corpo violentado que se esvai e se dilacera.

Longe estamos dos dispositivos de mediação da cultura civilizada que sugere que, entre desejos conflitivos, intervenha persuasão, linguagem e embate político.

A castração é uma experiência necessária e protegida que permite ao sujeito reconhecer psiquicamente limites e, então, necessariamente, possibilidades. Freud (1905/1993) a descreveu como um acontecimento intrafamiliar, como o afastamento do objeto mãe do filho que precisa abandoná-la para reconhecer-se, não apenas como parte do corpo fusionado, representado pela experiência física com o seio materno, mas também na cultura e na sociedade à qual pertence.

Nesse sentido é que, tal como descrevem Mano Brown e Alba Zaluar, o ethos guerreiro, o resgate da virilidade, pode passar - e por que não? - a ser realizado de forma onipotente, retirando do outro, à força, aquilo que de outro modo não seria possível obter no presente ou no futuro próximo. Tudo o que é oferecido não se pode ter, salvo com uma arma na mão. A equação consumista reencontra sua ordem, e o paradoxo é provisoriamente superado.

O tênis de marca, o relógio, a vida que pode ser arrancada revelam um empenho do despossuído em possuir. Aquele que, por escambo, barganhou a própria vida não tem nada a perder ou, dito de outra forma, tem tudo a ganhar.

Os Racionais apontam o paradoxo: "27 anos contrariando as estatísticas: cada minuto conta".

Sabemos: os atrativos do mundo burguês, repleto de posses, marcas, lazer e visibilidade é uma ambição para todos. Todos querem negociar sua castração em troca de alguma posse.

A castração sem recompensa possível é traumática e relança permanentemente à morte e à dor psíquica. Retirar, possuir, arrancar tornam-se expedientes de uma sobrevida de posses cujo valor é inestimável. E, em nossa cidade, só a violência pode permitir aos pobres uma posse burguesa e uma vida semiburguesa curta e volátil.

Se o menino que vende balas ou faz malabarismos no farol soubesse de antemão que não tem a menor chance de inscreverse nos circuitos de conforto, riqueza e urbanidade, certamente seu caminho para o crime seria muitíssimo abreviado.

É isso que se vê nos locais onde o tráfico impera. Há diversos casos de filas de meninos que esperam a sua vez para ingressar no tráfico e participar do triunfo onipotente que ele permite. Eles sabem que o preço é o risco iminente da morte. Mas a morte já se avizinhava antes, quando não se tinha nada, "nem moto nervosa, nem mina da hora, nem roupa da moda". 
Fazem coro com esse sistema parte significativa das camadas médias e altas da população, que propagam eficazmente seu discurso e exigem a pena de morte, os massacres, a redução da maioridade penal. Diante disso, o jovem pobre tem ou não tem razão em querer viver e possuir tudo o mais imediatamente possível?

A sociedade apavorada, que insiste em reconhecer-se como vitimada precisamente porque não reconhece a autoria das violências que provoca e aquelas que não combate, encontra-se também, como a criança com arma na mão, regredida e impotente. Mas, diferentemente dos pobres, seu clamor é ouvido.

O pavor é um sentimento de desamparo psíquico em que as funções do ego estão desabilitadas. É um sentimento que impede o reconhecimento da complexidade e inibe o psiquismo, relegando-o a funções e ações imediatas e reativas. Para evitar a possibilidade de perder a vida, melhor eliminá-la desde a raiz.

Os meninos não têm medo - "é só alegria" -, diz um dos entrevistados de MV Bill no documentário Falcão: Meninos do Tráfico. Sem medo eles rumam para a própria morte. Sem medo, estão desprotegidos de si, mas se estivessem amedrontados o tempo todo, essa seria uma experiência insuportável.

Novos sujeitos psíquicos sobrevivem no agravamento e enraizamento dos sistemas violentos em nosso país, e novos desafios se impõem àqueles que ainda podem ter medo. 


\section{Paulo Cesar Endo}

Psicólogo, psicanalista, Doutor, prof. do Instituto de Psicologia da USP.

*Endereço para envio de correspondência:

Rua Tanabi, 162, ap. 12, Cep: 05002-010 - Água Branca - São Paulo

E-mail: pauloendo@uol.com.br

Recebido 06/03/2008; Reformulado 29/09/2008; Aprovado 02/10/2008

Arendt, H. (1998). O que é política? (R. Guarany, trad.). Rio de Janeiro: Bertrand Brasil. (Trabalho original publicado em 1993)

Arendt, H. (1999). Eichmann em Jerusalém: um relato sobre a banalidade do Mal (J. R. Siqueira, trad.). São Paulo: Companhia das Letras. (Trabalho original publicado em 1963)

Bicudo, H. (2002). Meu depoimento sobre o esquadrão da morte. São Paulo: Martins Fontes. (Trabalho original publicado em 1976)

Caldeira, T. P. R. (2000). Cidade de muros: crime, segregação e cidadania em São Paulo. São Paulo: Edusp/Editora 34.

Endo, P. C. (2005a). Sobre a violência: Freud, Hannah Arendt e o caso do índio Galdino. In J. Z. Neto (Org.), Identidades e crises sociais na contemporaneidade (pp. 245-260). Curitiba: UFPR.

Endo, P. C. (2005b). A violência no coração da cidade: um estudo psicanalítico. São Paulo: FAPESP/Escuta.
Freud, S. (1993). Tres ensayos de una teoria sexual. In S. Freud, Obras completas (Vol. 7). Buenos Aires: Amorrotu. (Trabalho original publicado em 1905)

Girard, R. (1998). A violência e o sagrado. São Paulo: Paz e Terra. (Trabalho original publicado em 1972).

Rodley, N. Relatório sobre a tortura no Brasil. Produzido pelo relator especial sobre a tortura da Comissão de Direitos Humanos da Organização das Nações Unidas (ONU).

Zaluar, A.(1985). A máquina e a revolta. São Paulo: Brasiliense.

Zaluar, A. (1998). Para não dizer que não falei do samba: os enigmas da violência no Brasil. In L. Schwartz, História da vida privada no Brasil (pp. 245-318). São Paulo: Companhia das Letras. 